\title{
Transcending from hunter gatherer pursuits while balancing customary cultural ideals with market forces of advanced Western societies: Extending the traditional boundaries of Indigenous Yolngu people of the Northern Territory of Australia
}

By:

\author{
Cecil A. L. Pearson \\ Senior Research Fellow, School of Management \\ Curtin University \\ GPO Box U1987 \\ Perth, Western Australia 6845 \\ Telephone: 61-8-9266 1340 \\ Facsimile: 61-8-9266 7897 \\ Email: Cecil.Pearson@cbs.curtin.edu.au
}

and

Sandra Daff

Specialist Indigenous Relations,

Rio Tinto Alcan, Gove Operations

PO Box 21

Nhulunbuy, Northern Territory, 0881

Telephone: 61-8-89875463

Facsimile: 61-8- 89875556

Email: sandy.daff@riotinto.com

\section{Prepared for}

International Journal of Cultural Studies 


\section{Transcending from hunter gatherer pursuits while balancing customary cultural ideals with market forces of advanced Western societies: Extending the traditional boundaries of Indigenous Yolngu people of the Northern Territory of Australia}

Cecil Pearson (PhD, UWA) is currently employed by Curtin University in the role of Senior Research Fellow and was the co editor of Research and Practice in Human Resource Management for a decade. His vocational background has been in teaching, engineering as well as academia, and he has published in the fields of education, engineering and management.

Sandra Daff was recently awarded the Graduate Certificate in Community Relations by the University of Queensland. Her vocational career began in the Western Australian Government Water Corporation. Later, in the Alcan Department of Community Services she designed and administered the inaugural ALERT Indigenous educational vocational initiative at Nhulunbuy, and has continued to provide leadership for the management and coordination of the programme. Sandra has been involved in a series of publications reporting outcomes of the ALERT initiative. 


\title{
Transcending from hunter gatherer pursuits while balancing customary cultural ideals with market forces of advanced Western societies: Extending the traditional boundaries of Indigenous Yolngu people of the Northern Territory of Australia
}

\begin{abstract}
As large multinationals move their operations into remote regions of the world imperatives of social responsibility and sound business pragmatism compel engagement of the marginalised local Indigenous people. This notion is particularly relevant for the mining industry in Australia, which is undertaken in remote regions, where the local Indigenous communities are significantly socio economically disadvantaged compared to other Australians. This paper reports the job related outcomes of Indigenous Yolngu people of East Arnhem Land in the Northern Territory of Australia who were participants of an unique vocational - educational programme installed by the multinational mining company Rio Tinto Alcan. These mainline jobs related outcomes are in two main areas: 1) Employment in mainline work at the Nhulunbuy refinery or the mine site, and 2) Entrepreneurial timber related business (milling timber, house construction, furniture manufacture). Both streams are inaugural achievements for these Indigenous Australians. The concluding sections present challenges for multinational corporations when anchoring the contextuality of rural Australian communities with institutional processes, structures and the contemporary technologies of the workplace.
\end{abstract}

\section{Keywords: Australia Indigenous Education Vocation Yolngu Mining Entrepreneurship}

\section{Introduction}

There is widespread recognition that the low labour force participation of Australian Indigenous people (Prime Minister's report, 2010) is a primary factor underpinning their significant socio economic disadvantage. The relatively lower health status and life expectancy (Bailie et al., 2008), poorer housing and unsanitary living conditions (McDonald et al., 2008) as well as the higher incarceration levels, suicide rates and poverty (Wurst, 2009) of Indigenous people compared to other Australians; conditions that are visibly worse in remote regions of the country, has encouraged the Federal Government to target jobs creation in rural regions through three main avenues. First, initiated in 1977 in a small number of Aboriginal communities, as a response to criticisms from both Indigenous Affairs policy makers and some Aboriginal community leaders (Arthur, 2002) Indigenous people were receiving unemployment payments without doing any work, was the Community Development Employment Projects (CDEP) scheme (Altman, Gray and Levitus, 2005). Second, acknowledging the particular disadvantage of Indigenous Australians in the labour market government mechanisms have been installed to assist Aboriginal people to establish their own small businesses, and there has been a geographic and sector spread of successful Aboriginal exercises (Foley, 2003; Open for Business, 2008) while a number of government sponsored endeavours have been less successful (Furneaux and Brown, 2008; RussellMundine, 2007). Last, there has been a prevailing assumption the Australian mining industry will provide employment opportunities in remote Aboriginal communities, but despite a resurgence of interest in Indigenous employment their engagement (following Mabo and Native Title legislation) remains relatively low (Brereton and Parmenter, 2008). 
Complexities of Australian Aboriginal culture compound the difficulty of developing strategies to optimise the benefits of Indigenous participation in the mining industry. The appearance of a homogenous Indigenous culture has been consciously created through the binding energy of kinship obligations and familial networks within settings of established protocols for mutual collective benefits (Foley, 2010; Kilpatrick, Field and Falk, 2003). But there are also discernible variances in language, art, and fundamentally different lifestyles (Altman, 2003) between urban and regional Aboriginal people. These dissimilarities attract forces of conciliation as the clash of commercial mainstream values and the maintenance of traditional ceremonial obligations can be a substantial barrier for Indigenous employment in Australian minerals sector.

Despite cross cultural awareness programmes being conducted by mining corporations a lack of understanding or respect for cultural differences can arise as racists attitudes. Indeed, the provided information can be overwhelming for non Indigenous Australians (Arbeláez-Ruiz, 2010) towards minority groups. A succession of mining corporations operating at Nhulunbuy have acknowledged racism is a complex problem in a multicultural workforce, and proven racist comments or discrimination is likely to attract an invitation to choose an isle or window seat on the next departing flight. Foley (2006:15) succinctly portrays the issues for mining companies operating in Australia with the words “... Indigenous cultural values are often elusive, complex and contestable...”, which encourages the installation of inclusive and comprehensive training and employment schemes that appreciate Aboriginal interests.

This paper presents over four years of data and has potential to contribute to paradigms for better addressing the persistent poor socio economic conditions of Australian Aboriginals. Specifically, the paper identifies emerging barriers for vocational-educational training of Indigenous people for employment in the Australian mining industry. A more positive feature of the paper is the set of timber related Indigenous social entrepreneurial endeavours being undertaken by the Gumatj Yolngu clan of the Indigenous people of East Arnhem Land. Interestingly, the latter venture was seeded by participants who withdrew from the initial vocational-educational programme to illustrate the relevance of strong cultural continuities. The setting is in the remote Gove Peninsula of East Arnhem Land of the Northern Territory (NT) of Australia, which is shown in Figure 1.

\section{(Put Figure 1 about here)}

\section{Individualism Versus Universalism in Education and Employment}

The cultural and linguistic diversity of Indigenous Australia ensured successive Australian governments grappled with Indigenous policy. Since Colonial times there have been two major streams of Indigenous Australian political reforms,

1) assimilation, and

2) self determination.

Formation of the first took some 160 years, but within a tenth of the time the pivotal reform of self determination was introduced. Although there has been tinkering with the latter policy education and employment has been persistently advocated as the way to resolve the Australian Aboriginal problem, but success has been elusive. For instance, the model of social transition of Indigenous people after the 1967 referendum was administered differently by the Labor and Liberal governments (Hughes and Warin, 2005) with outcomes of fragmented remote unsustainable communities and suburban fringe settlements. Political manipulation by the Howard Liberal government was reflected in intense scrutiny of the previous Hawke and Keating Labor governments institutional reforms and later abolition of the Aboriginal and 
Torres Strait Islander Commission. A radical reform of the Commonwealth administration of Aboriginal Affairs made the political landscape less sympathetic to Aboriginal rights (Anderson, 2007), while compulsory Federal government legislation of the 1990s serendipitously led to a resurgence of interest in Indigenous employment in the Australian minerals industry (Barker, 2006; Cheshire, Everingham and Pattenden, 2011; Parsons, 2008). Now within the grasp of Australian Indigenous people is the opportunity to delineate their expectations of relevant education and training for sustaining their communities (Enhancing Indigenous Economic Independence, 2007; Pearson, 2007).

\section{Education for Expectations}

In spite of the considerable investments by successive Australian governments the Australian Indigenous people are arguably the most disadvantaged identifiable group within the national society (Commonwealth of Australia, 1991; Wild and Anderson, 2007). A great deal of literature shows Australian Indigenous people are likely to experience lower life expectancy; higher incidence of obesity, diabetes and cardiovascular diseases from dietary intake (Rowley et al., 2000); and high levels of common infectious diseases (e.g. diarrhoea, parasitic, eye), which can be attributed to unsanitary living conditions preventable by education for better hygiene behaviours (washing hands) (McDonald et al., 2008). Other literature reveals Indigenous Australians are likely to have lower incomes, lower labour market participation, and higher incidence of substance abuse (Altman, 2009; Krieg, 2006), which are factors recognised to underlie poverty. A line of discourse was advanced (Gray and Hunter, 2002; Reynolds, 2005) that these gross inequalities manifest from a lack of education, which leaves Australian Indigenous people vulnerable to unemployment. But education conceptions, that have drawn heavily on cultural separation and discounted Indigenous perspectives (Nichol, 2008) have generally, been lamentably unsuccessful (Johns, 2011). Contemporary contributors suggest the pathway to social reconciliation between Indigenous and non Indigenous people lies in education anchored in Indigenous forms of learning (Harrison, 2010; Harrison and Greenfield, 2011) to take into account Aboriginal epistemology (Yunkaporta, 2009) to improve post school transition into training and employment.

Australian Indigenous affairs policy has manifested major impacts on the employment of Indigenous Australians. Kaplan-Myrth (2005) provides a bleak account of how a series of government policies (since 1788) compelled Australian Indigenous people to be segregated, and their confinement to Missions and government centres (where they were given sustenance, medical treatment, education and training) provided the pastoral industry and other non Indigenous enterprises with unpaid labour, while curtailing any Indigenous commercial activity (Smith, 2006). Even more abhorrent was the actions of pastoralists in East Arnhem Land from 1860 to 1908 when they decimated Indigenous clans for their land to operate cattle stations (Trudgen, 2000). By the 1950s trusteeship of the Indigenous society centred on the official Australian policy of assimilation, a notion embracing the concept that Australian Aboriginals would eventually be integrated into a community exhibiting the beliefs and customs of non Indigenous Australians. Under mounting international pressure from the Church, politicians and lobbyists a constitutional referendum was conducted in 1967 leading to the introduction of the broad policy of self determination by the Whitlam commonwealth government in 1972 (Altman, Biddle and Hunter, 2005; Anderson, 2007; Sanders, 2002).

A most prominent effect of the policy of self determination was the 1970s outstations movement. Freed of encumbrances the Indigenous people, and particularly those in the NT, moved back to their traditional ancestral lands to establish small communities, referred to as outstations where the people were able to institute the customary sector of their traditional 
economy, which is based on wildlife harvesting (Altman, 2003). The Australian government was then obliged to decentralise appropriate institutional support and adequate resources in such services as health, education, and transportation to ensure the wellbeing of those isolated communities. Notable, was the provision of welfare payments as a support mechanism within the government policy of social inclusion, which is a conviction all Australian citizens should have the opportunity to participate in economic, social and community life (Brown, 2009).

Endeavours to transition the policy of self determination have been complicated by stakeholder assumptions. Withdrawal of the Missions (Yirrkala closed in 1975) was not satisfactorily replaced with Indigenous community councils to expose flawed philosophical underpinnings of self determination. More pertinent was the dependency for welfare, which instead of developing collective and individual responsibility, has according to Pearson (2007) led to the collapse of social norms and the emergence of violence, suicide, alcoholism, child abuse and heavy substance abuse (Krieg, 2006; Lee et al., 2009; Wurst, 2009).

Faced with mounting criticisms from the wider community, that Indigenous people were being paid welfare without doing any work, the Australian government introduced the CDEP scheme. Although the scheme had three major positive features,

1) the building of a strong functional sustainable and socio cultural base for individuals,

2) increased access to labour market participation, and

3) allowed communities to engage in a fundamentally different customary economy to the dominant Australian context (Altman et al., 2005),

there was scant evidence to show Indigenous people moved into the main stream labour market (Arthur, 2002). Moreover, with the abolition of the Aboriginal and Torres Strait Islander Commission in 2004, that was responsible for the administration of the scheme, the Australian government set a path to restructure the scheme into a work readiness training programme under the control of the Federal Department of Employment and Workplace Relations.

The Australian Federal Government has also targeted job creation in two other avenues. These avenues are,

1) commitment to developing Indigenous business opportunities for economic independence, and

2) strengthening a prevailing assumption the mining industry will provide Indigenous people in remote regions with employment.

There is a developing contemporary literature of Australian Indigenous entrepreneurship, but it will not be dealt with in detail in this paper. What will be acknowledged is the European written records reveal the Yolngu people were engaged in extensive trade with the Macassares (from the Celebes) from the $17^{\text {th }}$ century (Berndt and Berndt, 1999; Russell, 2004; Worsely, 1955) until the licenses were revoked by the South Australian government in 1904. This entrepreneurial heritage may be the foundation for the recent emergence of a Yolngu timber business, that will be outlined later in the paper.

The Australian mining industry is intimately connected with government regulations. Unlike many other Australian industries not only are the products controlled by government regulations, but there is extensive taxation on activities and exports, which have to be borne by the miner (Banks, 2003). Government controls are pervasive in work practices, encompassing both specific and generic award provisions in the pursuit of robust occupational health and safety as Australian mining and refinery sites are physically and emotionally 
demanding on workers. Indeed, Australian mine and refinery workers have the longest working hours of any industry in Australia (Colley, 2005) requiring employees to work long shifts of 12 hours or more, in rostered patterns, making fatigue issues a major problem for management. The pervasiveness of regulation ensures unqualified and uncertified people can neither enter mining infrastructure or establishments nor may they operate any facility, equipment or apparatus at mining/refinery sites. Moreover, at all times personal protective equipment must be worn. In addition, regular random medical inspections are conducted and any evidence of substance abuse results in immediate suspension and likely termination of employment. Given their lack of education and relevant training, poorer health, a preference not to wear bulky constrictive clothing, and challenges to balance family and community obligations discourages Australian Indigenous participation in Australian mining. But recent legislative reforms have led to mining companies taking a more proactive approach to preparing Australian Indigenous people for employment in the minerals industry.

\section{Foundations of Indigenous Employment and Training Provisions}

A contemporary assumption, that the establishment of a minerals extraction facility in a remote region of Australia will lead to significant sustainable Indigenous mainline employment, is worthy of re-examination. From 1788, when Captain Phillip sailed into Botany Bay to assert the Crown's acquisition of sovereignty over the several parts of Australia, until 1993 the minerals extraction sector operated under the notion of terra nullius (vacant land belonging to no one) (see Proclamation of Governor Bourke, 10 October 1835). Indigenous people who lived in the region of the mining operations were displaced (Crawley and Sinclair, 2003), and although some local Indigenous people did work in menial tasks (Barker, 2006) most were excluded. In particular, the abject treatment of the Yolngu people on the Gove Peninsula in the 1960s is well reported by Galarrwuy Yunupingu OA (2009) when he writes.

Now it is the early 1960s and a man called Harry Giese, the so-called protector of Aborigines in the Northern Territory stands on a 44 -gallon drum at the Yirrkala airport. He has called some people together to give them news - I am one of those people; my father is there also; Roy and Mawalan Marika; the Djapu leaders, too. A mine will be built here at Yirrkala, he tells us. It will mine the dirt that we stand on - our soil. The mining companies are coming and they will mine the land. They will take all the land and the boundary of that land will run to the edge of Yirrkala, and Yirrkala will be badly affected. Giese talks for 20 minutes, then he gets in his car and drives away. This is the first mining agreement on the Gove Peninsula. (p.34).

Despite a Bark Petition to Canberra in 1963, and a subsequent appeal to the Darwin Supreme Court contesting the mining proposal construction of the mineral extraction and refining facilities commenced and the operations were commissioned in 1972.

In 1992 the perspective held by the pastoralists and miners, that the Australian outback was empty and vacant, was profoundly changed. Eddie Mabo, David Passi, and James Rice, all descendants of the Merian people, challenged in the High Court of Australia the earlier annexation of the Murray Islands in Torres Strait by the Queensland Government. Their claim was the Merian people had lived on the islands in a subsistence economy based on cultivation and fishing prior to European contact. In a landmark case on $3^{\text {rd }}$ June 1992 the notion of terra nullius was declared irrelevant. By a majority of six to one the High Court ruled, as put by the 
Chief Justice, Gerrard Brennan. "The fiction by which the rights and interests of Indigenous inhabitants in land were treated as non - existent was justified by a policy which has no place in the contemporary law of this country.” (Mabo v Queensland (No 2), 1992: 21). In a historic decision (commonly referred to as Mabo) it was recognised the prior rights of Australian Aboriginals and Torres Strait Islanders were similar to those of Indigenous groups in other parts of the world.

The Mabo decision obliged the Australian government to introduce mechanisms for dealing with Indigenous rights. These rights, possessed at the time the British Crown claimed sovereignty, are to receive protection from the Australian common law. In 1993 the Keating government introduced legislation to deal with the implications of the Mabo High Court decision and other relevant legislation (e.g. Aboriginal Land Rights 1976, Pitjantjatjara Lands Act 1981) by establishing procedures to retrospectively validate the land titles of occupiers, and to set mechanisms for addressing Native Title claims. Indigenous groups, in a historic compromise, accepted the validation feature in exchange for guaranteed rights of the Traditional Owners, on whose ancestral lands are the mineral resources (and their representatives) to negotiate in land use agreements.

The recent substantial Australian legal developments coupled with international policy discourse have shaped commitment to deliver employment opportunity for Indigenous people. Prior to the 1993 legislation various International Conferences (e.g. International Covenants on Human Rights 1985, International Labour Organisation Convention 169 1989) were prominent events that rekindled interest in Indigenous wellbeing. Relevant to the mining industry the peak body of the International Council of Mining and Metals (ICMM, 2008) has endorsed policies that are reflected in the operating procedures of particular mining companies to foster employment and training provisions within the negotiated land use agreements. In Australia, the Federal government and the Minerals Council of Australia have signed a memorandum of understanding committing both parties to deliver better outcomes for remote Indigenous communities. In addition to the direct financial benefits as well as long term outcomes for the Indigenous community, often a common feature of the land use agreement is provision for employment and training of local people. Consequently, a number of mining companies have implemented employment, training and procurement strategies as a contribution to ensuring sustainable community benefits. Within these foundations is the vocational-educational initiative that has been installed by Rio Tinto Alcan at Nhulunbuy.

\section{Methodology}

Site

On the Gove Peninsula the international mining company Rio Tinto Alcan operates the largest alumina refinery in the southern hemisphere. Bauxite ore is transported from the mine site (by a conveyor belt system of some $18 \mathrm{~km}$ ), and refined to alumina by the Bayer process. This mineral extraction complex is the largest employer in the NT, and many of the employees reside in the 'closed' town of Nhulunbuy, which has all the facilities (e.g. hospital, airport, shopping complex, government services) of a contemporary township.

\section{Participants}

The participants of the study are Indigenous Australians. In May 2007 when an inaugural vocational-educational training programme was installed by the mining company (then Alcan Gove) the participants came from the adjacent small hamlets (i.e. Galupa, Galaru, Gunyangara) or Yirrkala (shown in Figure 1) as they had to be transported to and from the training centre by the mine company bus (Daff and Pearson, 2009). Initially, the participants 
were from the Yolngu nation of clans as these people were the descendants of their forebears who had been the occupiers of the land for some 50,000 years. Greater exposure of the vocational-educational programme now has participants from across several states of northern Australia.

\section{Procedure}

Prior to the commencement of the vocational-educational programme a number of initial actions had to be completed. On the direction of Executive Management the proposal to install the training programme was articulated in a comprehensive document to gain widespread support from national and local Indigenous groups, the Traditional Land Owners, the three levels of government, peak industry bodies, the mining sector, and the business community. A special training centre was built on the outskirts of Nhulunbuy, and the two main buildings were equipped with teaching resources as well as engaging qualified teachers, administrative and supervisory personnel. Registered training organisations (e.g. Charles Darwin University) were engaged to deliver work integrated learning programmes to content and pedagogical requirements of the Federal Department of Educational Employment and Workplace Relations. In addition, there was a myriad of arrangements, too many to list here, that had to be completed to meet the first intake of participants in May 2007. Compiling all these activities led to the programme being identified as the Arnhem Learning Educational and Regional Training (ALERT) scheme.

Since inception ALERT has been progressively refined. The primary function of ALERT is to prepare Indigenous people, who have roots in a fundamentally different customary economy based on wildlife harvesting, to work in the highly complex, shift regimented, physical and emotionally demanding regime of mineral extraction operations. Consequently, the initial expectations were ALERT participants would require a minimum of seven months of training before they would be prepared for mainline work with a further 29 months of additional on the job training. Currently, with better selection procedures and a wider spectrum of applicants it is possible to prepare ALERT participants for mainline work in three months, while others can begin employment at the refinery earlier. After completion of a comprehensive and rigorous selection procedure applicants are allocated to one of two streams of meaningful work outcome destinations 1) Work Ready or 2) Work Starts.

Work Ready and Work Starts are generic components of the ALERT scheme that provide flexibility and adaptability to meet the needs of the Indigenous applicants. Work Ready is the destination of applicants with lesser vocational and educational competencies. Important objectives of Work Ready are to instil work habits of attendance and punctuality, encouraging participants to listen and acquire practical work skills as well as knowledge so they can work either at the Nhulunbuy mining operations or in mainline jobs in the wider community. A tangible outcome is the Certificate 1 of Resources and Infrastructure Operations, which is awarded by the Charles Darwin University. Less than one half the students transition into Work Starts.

Work Starts provides a point of departure for several vocational opportunities and further educational outcomes. The several pathways to full time employment include secondment, apprenticeships, and traineeships. Work Starts enables participants to have casual employment with the mining company within an environment of pastoral care, involving Group Training Northern Territory and the opportunity to be awarded the Certificate 2, in a number of disciplines, by the Charles Darwin University. 
Following the recruitment process most ALERT applicants are participants of either Work Ready or Work Starts. However, the flexibility of the ALERT scheme enables competent applicants to be engaged in full time employment or other career paths on completion of the recruitment stage. The various vocational pathways for Indigenous candidates is shown as Figure 2.

(Put Figure 2 here)

\section{Measures}

The ALERT participants were scored by their work relevant outcomes. Every applicant of the ALERT programme is identified in the database. Some withdrawals from the vocationaleducational programme were voluntary (e.g. left to work on homelands), or involuntary (e.g. suspended, custodial sentence). Those participants who graduated from the programme were employed either by Rio Tinto Alcan or in the wider community and their workplace was identified. For those ALERT participants/graduates who remained in the region it was possible to follow their career paths as they 'job hopped'.

\section{Results}

The work relevant outcomes are shown in three parts. First, a review of the recruitment data and the job outcomes of the ALERT programme demonstrate Indigenous employment is a major challenge for the Australian mining sector. Second, greater delineation is given to ALERT graduates in terms of the attained qualification and their first job position in the community or Rio Tinto Alcan. This information is presented as Table 1. Last, commentary is made about the few ALERT participations who left the programme to work on their ancestral lands at the Garrathiya cattle station. Subsequently, a greater number of Yolngu people have shown enthusiasm to be involved in similar timber related entrepreneurial ventures.

A feature of the recruitment process was the leakage of applicants. From May 2007 until February 2011 there was a total of 337 applicants (by telephone, fax, email, presentation), but 199 (59.05 \%) did not continue when required to present documentation of formal education, work references or Aboriginal certification. Subsequent comments suggested a number of the applicants viewed ALERT as another welfare variant, but on realising investment would need to be made by them they discontinued their application. Some leakage of applicants could be attributed to low competency in English comprehension and poor health. The total number of Indigenous people who have been ALERT participants from May 2007 to March 2011 is 138.

The work relevant outcomes of the 138 Indigenous participants are shown as Figure 3. Overall, it is shown in Figure 3 some two thirds of the participants leave the programme, and within this group less than 15 per cent are employed in mainline jobs in the wider community. The data of Figure 3 reveal almost 16 per cent (15.94) are in main stream jobs at the refinery or the mine site. A further 16.66 per cent are in Work Ready or Work Starts, and expectedly about one third of these Indigenous participants will transition into mainline jobs either in the mining sector or the community. Rigorous recording of job outcomes of Indigenous people who 'aspire' to be ALERT participants reveal most remain in their remote communities.

(Put Figure 3 here)

Table 1 summarises educational and vocational attainments by the number of Indigenous ALERT participants. The number of ALERT trainees who have graduated with a Certificate 1 or a Certificate 2 are few, but outstanding, and numerically increasing annually. These 
recipients are the first Indigenous Yolngu to be awarded this achievement by the Charles Darwin University. Additionally Yolngu males, who are engaged in engineering apprenticeship, are prominent first events.

(Put Table 1 here)

Also shown in Table 1 is the current vocational destiny of ALERT participants. The Rio Tinto Alcan vocational values replicate the scores in the right hand boxes of Figure 3. However, the number of ALERT participants, who have employment in community mainline jobs is prudent as once these Indigenous people move away from the Nhulunbuy region their career path becomes less well known. In the Nhulunbuy region during the first three year of the programme, a total of 16 members chose to work on their homelands, and a majority (13) returned to their communities to work on specific tasks, usually a CDEP for the East Arnhem Shire. Indeed, three Indigenous people returned to the Gumatj Corporation cattle station at Garrathiya, some $100 \mathrm{~km}$ south south west of Nhulunbuy. There they have been productively engaged (with other non ALERT participants) in timber milling and dwelling construction (Pearson and Helms, 2010a).

The withdrawal of the three Yolngu men from the inaugural 2007 ALERT programme may have been the genesis of a developing Indigenous social enterprise. These three people became the core of a larger group of Indigenous Yolngu who selectively felled mature trees from the savannah forest and milled the logs to produce construction timber. Other Yolngu men with non Indigenous supervision constructed two high quality accommodation dwellings at the Garrathiya cattle station as a part of the greater goal to supply nearby outstations with cryovaced beef product (Pearson and Helms, 2010a). After the completion of this project there was further milling of timber at different locations, and this led to the construction of a large house at Dhanaya on the shore of Port Bradshaw (Pearson and Helms, 2010b). Realising the decorative feature of the milled timber (eucalyptus tetrodonta) a group of Indigenous Yolngu, with supervision by a non Indigenous cabinet maker from Melbourne, built a number of board room tables (valued at $\$ 3,500$ each). The greater ambition is to extend the learned skills to make a selection of robust timber furniture that will survive the wear and tear of overcrowded, intergenerational living, which is a normal condition of Indigenous housing. Currently, a number of Yolngu are involved with the construction of three homes at Gunyangara, and a further two on the outskirts of Nhulunbuy. These endeavours are not only providing tangible products for the clan, but the participating Yolngu are embarking on the magnificent obsession of building their future.

\section{Discussion}

The acknowledged disadvantage of Indigenous Australians is well documented, and consequently, has attracted a great deal of speculation how the problems might be resolved. Often the suggestions and recommendations have been provided by non Indigenous academics, bureaucrats, politicians, and interested people who collectively claim the solution lies in education and employment. While these global notions resonate with the wider community the delineation of programmes to engage these inextricably bound topics, to provide Indigenous Australians with sustainable futures are yet to emerge. It has been estimated by Dillion and Westbury (2007) across 86 per cent of Australia there are some 1200 remote Indigenous communities and the Australian governments (and their departments) have targeted three universal streams of unsubsidised work (i.e. CDEP, entrepreneurship, mining) as measures to attenuate the level of Australian Indigenous disadvantage. But after 34 years of endorsement of the CDEP scheme the intention is to restructure this political experiment into 
education and training. The claimed commitment to Australian Indigenous entrepreneurship also displays an absence of coherent policy. After terminating the Yolngu international trade in 1904, and installing mechanism to provide finance for the benefit of Aboriginal enterprises in the late 1960s, few Indigenous people are employed in sustainable enterprises (Australian Government, 2009). Last, is the prevailing assumption Indigenous people will pursue employment in the Australian mining industry to generate personal wealth and have better socio economic conditions by adopting lifestyles requiring regular adherence to mining rosters. The evidence provided in this paper reveals this universal notion is worthy of further examination.

The content of this paper has four notable features. First, is the scant disclosure of statistical data of Indigenous employment in the Australian mineral industry. Seldom do mining companies operating in Australia provide to the community comprehensive information about Indigenous vocational-educational programme pedagogy or content, the academic achievement of participants (voluntary and involuntary withdrawals, graduates), and the relevant work outcomes in main stream jobs (numbers of Indigenous people in specific jobs) (Bereton and Parmenter, 2008; Tiplady and Barclay, 2007). Conveniently, the scores are broadly expressed as percentages in a range of job types to hide missing data while avoiding the responsibility for accountability. The escape clause for the mining company is any vocational-educational achievements and work placements are sensitive and commercial dimensions of the land use agreements. Rio Tinto Alcan (Gove Operations) is to be commended for allowing the presentation of the material in this paper.

Second, the evidence is a high proportion of applicants did not proceed beyond the registration stage. After applicants confirmed their Aboriginality by certification, and then realising ALERT was not a variant of a government welfare programme, but there would be a requirement to make a personal investment in a vocational-educational programme, many did not proceed. This finding has foundation in a statement from Pearson (2007:26) who wrote welfare has been accompanied by a “... calamitous erosion of black responsibility.”. A further significant loss of applicants was due to substance abuse. Lee and colleagues (2008) state heavy cannabis use has become common in remote Indigenous communities as well as the misuse of tobacco, alcohol and petrol. Candidate exclusion was also due to English literacy and numeracy deficits. In 2007 and 2008 applicants with relatively low literacy and numeracy competencies were accepted, but many withdrew after exhibiting poor classroom behaviours and a disinclination to learn. Now candidates with less than upper primary school English and numeracy competencies are seldom accepted.

A third feature is the work relevant outcomes of the ALERT participants. Some Indigenous participants experienced the programme, but were involuntarily removed, while others left voluntarily to return to their communities often to be drawn into cultural pursuits or to begin work for the East Arnhem Shire. Some Indigenous participants, who completed the ALERT programme, elected to work at the mine site operating heavy equipment or at the refinery in a variety of main stream jobs (Daff and Pearson, 2009). A few Indigenous people graduated from the programme with a Certificate I in Resources and Infrastructure Operations and a lesser number with a Certificate II in streams of Administration, Engineering, or Metalliferous metals. These qualifications are awarded by the Charles Darwin University. Notable is the two Indigenous apprentices with one now in the second year. These achievements are substantial results as it is the first time an Australian Indigenous person has been awarded these qualifications or attained this trade status at this site. Moreover, since the Rio Tinto Alcan (Gove Operations) mine site and refinery were commissioned in 1972 these are the first 
Australian Indigenous people to work in main stream jobs at these facilities. The enormity of the importance of these achievements has been demonstrated at the graduation ceremony when parents of the graduates have become visibly emotional.

The fourth feature was the unexpected creation of a set of timber based Indigenous social enterprises. A social enterprise is a hybrid commercial model that blends economic and social value creation to bring solutions to critical social problems. Indigenous housing is a significant social problem being addressed by the Yolngu people who are milling timber on their ancestral lands some $100 \mathrm{~km}$ south south west of Nhulunbuy and building dwellings at Garrathiya, Port Bradshaw, Gunyangara and on the outskirts of Nhulunbuy. Three members of the inaugural 2007 ALERT programme were the initial core of the Indigenous social entrepreneurs of this venture, and through the leadership of Galarrwuy Yunupingu a number of timber related small businesses are now operating (timber milling, house construction, furniture) (Pearson and Helms, 2010a; 2010b; 2011). Undertaking these economic social and ecological benefits may have conveniently emerged with the departure of the three Indigenous participants of the ALERT programme. But it is also nice to believe their involvement with the vocational-educational programme may have been the impetus for the reinvigoration of the customary section of their lifestyle of wildlife harvesting while maintaining a strong spiritual and religious connection with their traditional lands when engaged in meaningful work. It is not uncommon to find an Indigenous employee, spear in hand (with wife and children walking behind) hunting in the savannah forest, yet the day before this man was operating mechanical or electrical equipment on a building site.

\section{Conclusion}

The notion Australian Indigenous people will be substantially represented in the workforce of remote mining operations to improve their socio economic status warrants revisitation. A prevailing assumption that Indigenous people would wish to acquire greater personal wealth and develop skills and competencies to enable opportunity to be employed in contemporary industrial work contexts is problematic. Australian Indigenous people are in a gift giving economy, referred to by the Yolngu as the process of humbugging. For instance, if a Yolngu person is at the checkout of Coles or Woolworths with a trolley of goods and has insufficient cash the strategy is to call out loudly in the mother tongue. Other Yolngu come and place money on the counter with the expectation in a similar situation they would also be 'gifted' any required money. Indigenous Australians who live in a remote region are engaged in a fundamentally different customary culture to the dominant capital intensive main stream national culture. An universalist view that Australian Indigenous people would want to accumulate assets and wealth is unlikely to be accurate given the value Aboriginals place on kin based relationships and utilitarian living. The point was made by a young Yolngu man to the authors at a spectacular beach with turquoise coloured waters, "You white people are mad. You work all your life to retire at a place like this. I can come here any day”. Clearly, universal strategies of Australia's social policy for improving the wellbeing of Indigenous people need to be challenged.

A salient implication of the information presented in this paper is the relevance of the phenomenon of crossvergence for Indigenous Australians. An important debate in the cross cultural management literature is individual behaviours are influenced by the converging effects of the dominant institutional rules and societal values or the diverging forces of communication networks and education. The observance of behavioural differences in geographically separate places has popularised the notion of an unique value system of crossvergence, which is a synergistic state from the combination of the convergence and the 
divergence elements. Indigenous Australians have a different culture and are influenced by a holistic spiritual view of the world (Dreamtime), which is very different to the dominant society in which they are embedded, and the presented evidence shows the Indigenous subjects adopted strategies and tactics to pursue their preferences and expectations. Indeed, highlighted in the paper is the Indigenous people strengthened their cognitive processes enabling the development and acquisition of skills and behaviours to achieve considered successful outcomes in work structures substantially different, and incongruent with the culture of their hunter gatherer backgrounds. Crossvergence is also practiced within the global landscape by contemporary organisations searching for competitive advantage, nominally expressed as sustainable cross cultural business encounters, when engaging stakeholders from diverse nationalities and holding different dispositional nuances. Indigenous Australians are also challenged to search for a fine balance between tradition and change. Their journey of crossvergence is conducted in the narrower local or national arenas, but this lesser geographical expanse has not been less inhibiting. The sobering evidence is few Australian Indigenous people were able to sharpen their core beliefs and deep rooted ancient values to make them context relevant with the dominant Australian system. 


\section{References}

Altman, J. C. (2003) 'People on Country, Healthy Landscapes and Sustainable Indigenous Futures: The Arnhem Land Case', The Drawing Board: An Australian Review of Public Affairs 4(2): 65-82.

Altman, J.C. (2009) Beyond Closing the Gap: Valuing Diversity in Indigenous Australia, CAEPR Working paper No. 54/2009. Canberra, Centre for Aboriginal Economic Policy Research: The Australian National University.

Altman, J.C. N. Biddle and B. H. Hunter (2005) 'A Historical Perspective on Indigenous Socioeconomic Outcomes in Australia, 1971-2011', Australian Economic History Review 45(3): 273-295.

Altman, J.C. M.H. Gray and R. Levitus (2005) Policy Issues for the Community Development Employment Projects Scheme in Rural and Remote Australia. Canberra, Centre for Aboriginal Economic Policy and Research: The Australian National University.

Anderson, I. (2007) ‘The End of Aboriginal Self-Determination?’, Futures 39(2/3): 137-154.

Arbeláez-Ruiz, D.C. (2010) Mining Supervisors Experiences in Working with Indigenous Employees: Perspectives on Leadership, Training, Development and Promotion. School of Philosophy, Anthropology and Social Enquiry, Faculty of Arts: The University of Melbourne.

Arthur, W.S. (2002) Autonomy and the Community Development Employment Projects scheme. Canberra, Centre for Aboriginal Economic Policy Research: The Australian National University.

Australian Government (2009) Indigenous Small Business Owners in Australia. Canberra: Australian Taxation Office.

Bailie, R.S. D. Si, M.C. Dowden, C.M. Connors, L. O’Donoghue, H.E. Liddle, C.M. Kennedy, R. J. Cox, H.P. Burke, S.C. Thompson and A.D.H. Brown (2008) 'Delivery of Child Health Services in Indigenous Communities: Implications for the Federal Government's Emergency Intervention in the Northern Territory', Medical Journal of Australia 188(10): 615-618.

Banks, G. (2003) Minimum Effective Regulation and the Mining Industry. Address to the Minerals Council of Australia's Annual Industry Seminar. Canberra: Old Parliament House.

Barker, T. (2006) Employment Outcomes for Aboriginal People: An Exploration of Experiences and Challenges in the Australian Minerals Industry. Brisbane, University of Queensland: Centre for Social Responsibility in Mining, Sustainable Minerals Institute.

Berndt, R.M. and C.H. Berndt (1999) The World of the First Australians: Aboriginal Traditional Life Past and Present, Canberra: Aboriginal Studies Press. 
Brereton, D. and J. Parmenter (2008) 'Indigenous Employment in the Australian Mining Industry', Journal of Energy and Natural Resources Law 26(1), 66-79.

Brown, J. (2009) What's Next for Welfare - to - Work?, Issue Analysis,117, 1-15. URL (Consulted April 2010): http://www.cis.org.au/issue_analysis/IA117/IA117.pdf.

Cheshire, L. J-A. Everingham and C. Pattenden (2011) 'Examining Corporate Sector Involvement in the Governance of Selected Mining Intensive Regions in Australia', Australian Geographer 42(2): 123-138.

Colley, P. (2005) A Career and a Life in Mining: What Needs to be Done? Paper presented at to the Sustainable Development 2005 Conference of the Minerals Council of Australia, Alice Springs, Australia.

Commonwealth of Australia (Commissioner E. Johnston) (1991) Royal Commission into Aboriginal Deaths in Custody. National Report, Vols.1-4. Canberra: Australian Government Printer.

Crawley, A. and A. Sinclair (2003) 'Indigenous Human Resource Practices in Australia Mining Companies: Towards an Ethical Model', Journal of Business Ethics 45(4): 361373.

Daff, S. and C.A.L. Pearson (2009) 'Indigenous Employment: The Rio Tinto Alcan Initiative in Northern Australia', Journal of Contemporary Issues in Business and Government 15(1): 1-20.

Dillon, M.C. and N.D. Westbury (2007) Beyond Humbug: Transforming Government Engagement with Indigenous Australia. West Lakes, South Australia: Seaview Press.

Enhancing Indigenous Economic Independence (2007) A Report to the Minister for Families, Community Services and Indigenous Affairs, the Hon. Mal Brough. Prepared by the Economic Independence Sub-Committee of the National Indigenous Council and endorsed by the Council on 19 June 2007.

Foley, D. (2003) 'An Examination of Indigenous Australian Entrepreneurs', Journal of Developmental Entrepreneurship 8(2):133-151.

Foley, D. (2006) Indigenous Australian Entrepreneurs: Not all Community Organisations, not all in the Outback. Canberra, Centre for Aboriginal Economic Policy Research: The Australian National University.

Foley, D. (2010) 'The Function of Social (and human) Capital as Antecedents on Indigenous Entrepreneurs Networking', New Zealand Journal of Employment Relations 35(1): 65-88.

Furneaux, C.W. and K.A. Brown (2008) 'Australian Indigenous Entrepreneurship: A Capital -Based View’, Entrepreneurship and Innovation 9(2): 133-144.

Gray, M.C. and B.H. Hunter (2002) 'A Cohort Analysis of the Determinants of Employment and Labour Force Participation: Indigenous and Non-Indigenous Australians, 1981 to 1996’, The Australian Economic Review 35(4): 391-404. 
Harrison, N. (2010) 'Teaching Indigenous Perspective in the Twenty-First Century Classroom: An Exploration of Quality Pedagogy in Australian Schools', in G. Vanessa and S. Cherrington (eds) Delving into Diversity: An International Exploration of Issues of Diversity in Education (pp. 99-107). New York: Nova Science.

Harrison, N. and M. Greenfield (2011) 'Relationship to Place: Positioning Aboriginal Knowledge and Perspectives in Classroom Pedagogies', Critical Studies in Education 52(1): 65-76.

Hughes, H. and J. Warin (2005) 'A New Deal for Aborigines and Torres Strait Islanders in Remote Communities,’ Issue Analysis 54: 1-20.

ICMM (International Council on Mining and Metals). (2008) Position Statement: Mining and Indigenous Peoples’ Issues. London: ICMM.

Johns, G. (2011) Aboriginal Self-Determination: The White Man's Dream. Ballan, Victoria: Connoncourt.

Kaplan-Myrth, N. (2005) 'Sorry Mates: Reconciliation and Self-determination in Australian Aboriginal Health’, Human Rights Review 6(4): 69-83.

Kilpatrick, S. J. Field and I. Falk (2003) 'Social Capital: An Analytical Tool for Exploring Lifelong Learning and Community Development', British Educational Research Journal 29(3): 418-433.

Kreig, A.S. (2006) 'Aboriginal Incarceration: Health and Social Impacts', Medical Journal of Australia 184(10): 534-536.

Lee, K.S.K. A.R. Clough, M.J. Jaragba, K.M. Conigrave and G.C. Patton (2008) 'Heavy Cannabis use and Depressive Symptoms in these Aboriginal Communities in Arnhem Land, Northern Territory', Medical Journal of Australia 188(10): 605-608.

Mabo v Queensland (No 2). (1992) High Court of Australia HCA 23; (1992) 173 CLRI (3 June 1992) URL (Consulted February 2012): Mabo and Others V Queensland http://www.austlic.edu.au/au/cases/cth/high_ct/175clrl.html

McDonald, E. R. Bailie, D. Brewster and P. Morris (2008) 'Are Hygiene and Public Health Interventions Likely to Improve Outcomes for Australian Aboriginal Children Living in Remote Communities? A Systematic Review of the Literature', BioMed Central 8(153), URL (Consulted April 2010): http://www.biomedcentral.com/1471-2458/8/153.

Nicol, R. (2008) 'Pedagogical Issues Affecting Indigenous Citizenship and Education in Australia and Melanesia', Paper presented to the Social Educators' Association of Australia Biennial Conference, Multidimensional Citizenship Education in a Changing World 20-22 January 2008, University of Newcastle.

Open for Business (2008) Developing Indigenous enterprises in Australia. Canberra: Commonwealth Printing and Publishing Office. 
Parsons, R. (2008) 'We are all Stakeholders now: The Influence of Western Discourses of “Community Engagement” in an Australian Aboriginal Community', Critical Perspectives on International Business 4(2/3): 99-126.

Pearson, N. (2007) 'White Guilt, Victimhood and the Quest for a Radical Centre', Griffith Review 16: 58.

Pearson, C.A.L. and K. Helms (2010a) 'Releasing Indigenous Entrepreneurial Capacity: A Case Study of the Yolngu Clan in a Remote Region of Northern Australia', Global Business and Government Review 12(1/2): 72-84.

Pearson, C.A.L. and K. Helms (2010b) 'Building Social Entrepreneurship in a Remote Australian Indigenous Community: The East Arnhem Land Housing Construction Case', Journal of Australian Indigenous Issues 13(4): 2-18.

Pearson, C.A.L. and K. Helms (2011) 'Indigenous Entrepreneurship in Timber Furniture Manufacturing: The Gumatj Venture in Northern Australia', Information Management and Business Review 2(1): 1-11.

Prime Minister's Report (2010) Australian Government, Department of Family, Housing, Community Support and Indigenous Affairs Report. URL (Consulted January 2011): http://www.fahcsia.gov.au/sa/indigenous/pubs/general/Documents/ClosingtheGap2010/des criptions.htm\#19.

Reynolds, R.J. (2005) 'The Education of Australian Aboriginal and Torres Strait Islander Students', Childhood Education 82(1): 31-36.

Rowley, K.G. M. Daniel, M.Skinner, G.A. White and K. O’Dea (2000) 'Effectiveness of a Community - Directed 'Healthy Lifestyle' Program in a Remote Australian Aboriginal Community’, Australian and New Zealand Journal of Public Health 24(2): 136-144.

Russell, D. (2004) 'Aboriginal-Makassan Interactions in the Eighteenth and Nineteenth Centuries in Northern Australia and Contemporary Sea Rights Claims', Australian Aboriginal Studies 1: 3-17.

Russell-Mundine, G. (2007) 'Key Factors for the Successful Development of Australian Indigenous Entrepreneurship’, Tourism Preliminary Communication 55(4): 417-429.

Sanders, W. (2002) Towards an Indigenous Order of Australian Government: Rethinking Self-Determination and Indigenous Affairs Policy. Canberra, Centre for Aboriginal Economic Policy Research: Australian National University.

Smith, A. (2006) 'Indigenous Development - Without Community, Without Commerce', Australian Review of Public Affairs URL (Consulted October 2008): http://www.australianreview.net/digest/2006/09/smith.html

Tiplady, T. and M.A. Barclay (2007) Indigenous Employment in the Australian Minerals Industry. Brisbane, Centre for Social Responsibility in Mining Institute: The University of Queensland. 
Trudgen, R. (2000) Why Warriors Lie Down and Die. Darwin: Aboriginal Resource and Development Services Inc.

Wild, R. and P. Anderson (2007) Ampe Akelyernemane Meke Mekarle: Little Children are Sacred, Report of the Northern Territory Board of Inquiry into the Protection of Children from Sexual Abuse. URL (Consulted February 2012): www.nt.gov.au/dcm/inquirysaac/pdf/bipacsa_final_report.pdf

Worsely, P.M. (1955). 'Early Asian Contacts with Australia’, Past and Present 7(1): 1-11.

Wurst, T. (2009) Suicide in North East Arnhem Land: An Overview of the Suicide Trends amongst the Population of East Arnhem Land from January $1^{\text {st }} 2007$ to December $31^{\text {st }}$ 2008. Northern Territory: Nhulunbuy Police Station.

Yunkaporta, T. (2009) 'Aboriginal Pedagogies at the Cultural Interface', PhD Thesis, James Cook University,

Yunupingu, G. (2009) 'Tradition, Truth and Tomorrow', The Monthly December 2008 January 2009: 32-40. 
Figure 1. The study site.

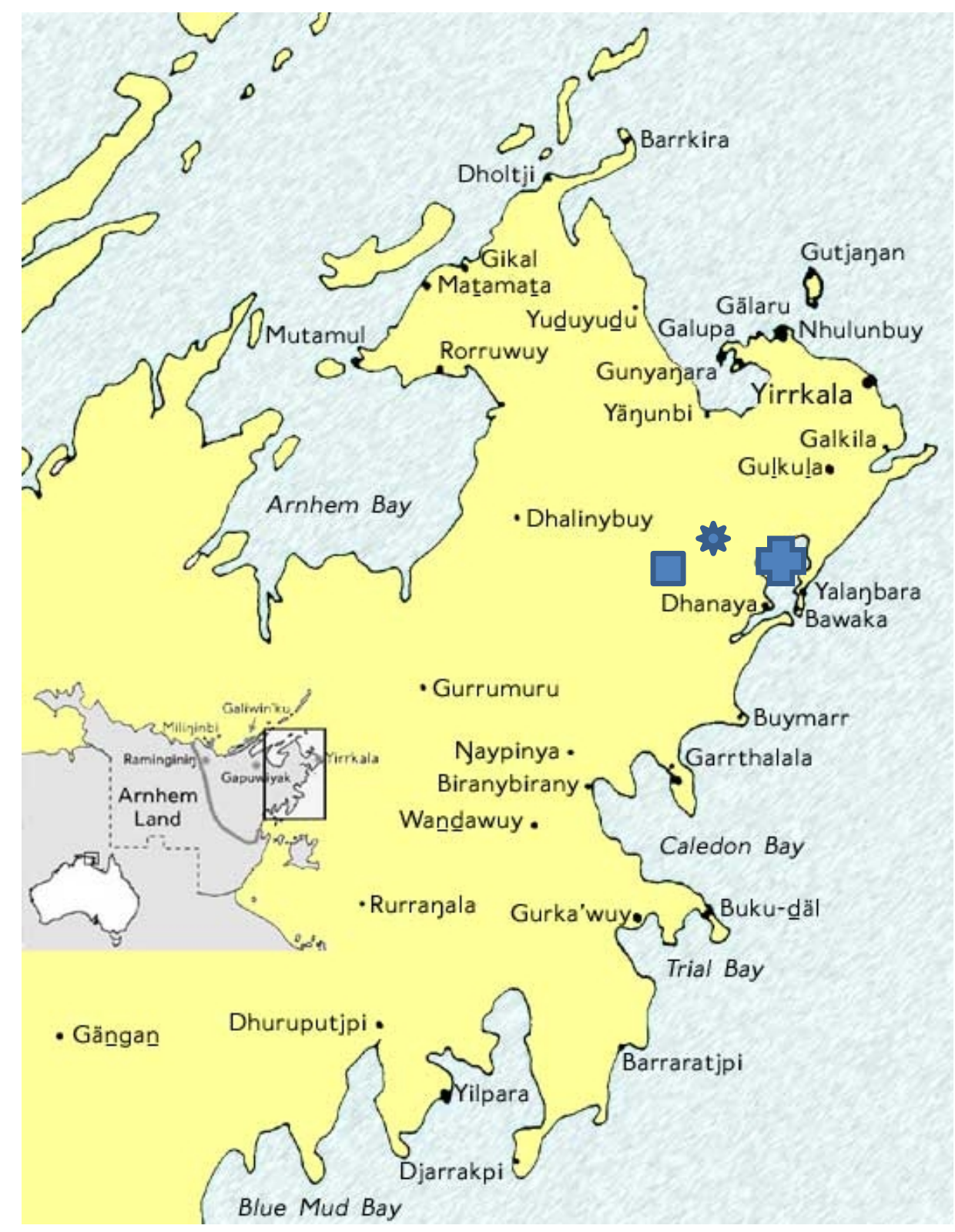

Note: Represent the location of Port Bradshaw, represents the site of timber milling, and $\square$ the location of the Garrathiya cattle station. All locations except Gunyangara, Nhulunbuy and Yirrkala are outstations with populations less than 100 people. 
Table 1. ALERT Programme Accomplishments

\begin{tabular}{cclc}
\hline $\begin{array}{c}\text { Educational } \\
\text { Certificate 1 }\end{array}$ & \multicolumn{1}{c}{ Vocational } \\
2007 & 7 & Full Time Employment by RTA & 13 \\
2008 & 9 & Work Starts and Secondments & 9 \\
2009 & 11 & Apprenticeships & 14 \\
2010 & 15 & Traineeships & 2 \\
2011 & 36 & & 6 \\
Certificate 2 & & Community & \\
2009 & 2 & & \\
2010 & 2 & & \\
2011 & 3 & & \\
\hline
\end{tabular}

Note.

Certificate 1 in Resources and Infrastructure Operations.

Certificate 2 is a GTNT in a variety of streams such as Administration, Engineering or Metalliferous Mining Operations. 
Figure 2

RTA ALERT PROGRAMME PATHWAYS

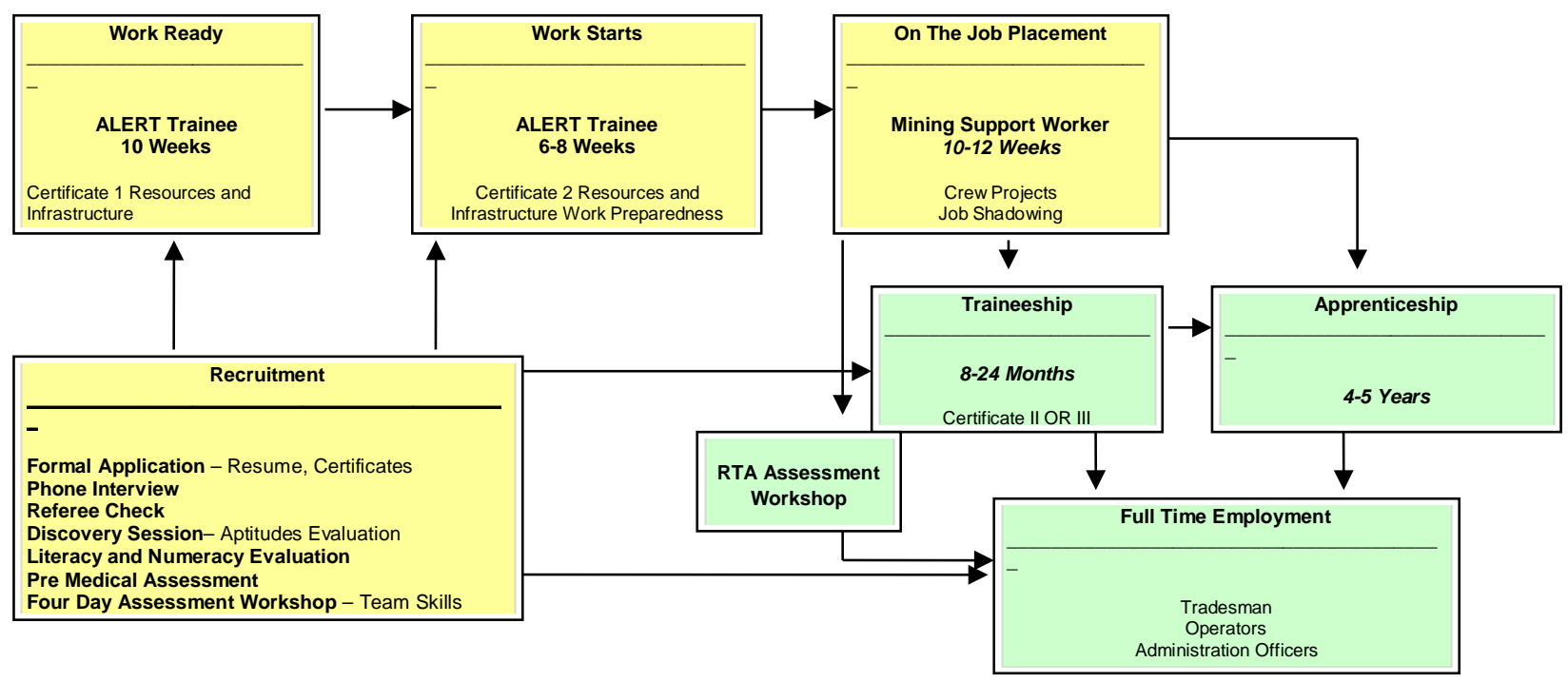

Note. RTA = Rio Tinto Alcan, and

ALERT $=$ Arnhem Learning Educational and Regional

Figure 3

\section{ALERT OVERALL Programme Retention 2007- 31st March 2011}

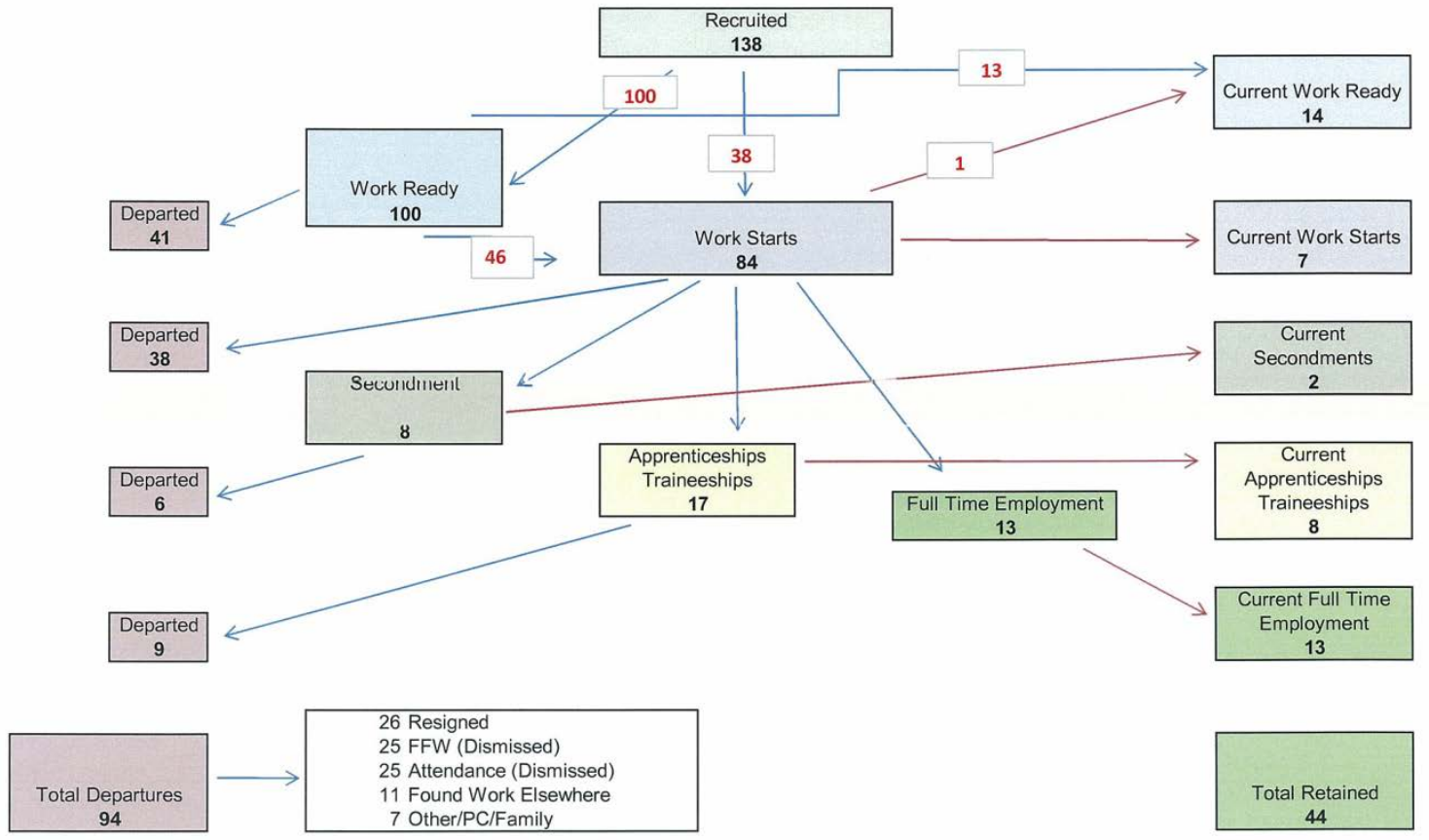

